\section{Fertigation Frequency Affects Growth and Water and Nitrogen Use Efficiencies of Swingle Citrumelo Citrus Rootstock Seedlings}

\author{
Juan Carlos Melgar', Arnold W. Schumann, and James P. Syvertsen \\ Citrus Research and Education Center, University of Florida/IFAS, 700 \\ Experiment Station Road, Lake Alfred, FL 33850
}

Additional index words. daily ET, pulsing, root/shoot dry weight ratio, leaf photosynthesis, transpiration

\begin{abstract}
We determined if frequency of application of irrigation water plus fertilizer in solution (fertigation) could modify root and shoot growth along with growth per unit nitrogen $(\mathrm{N})$ and water uptake of seedlings of the citrus rootstock Swingle citrumelo growing in a greenhouse. In the first experiment, all plants received the same amount of water with sufficient fertilizer $N$ but in three irrigation frequencies applied in $101.5-\mathrm{mL}$ pulses per day, one 15-mL application per day, or $45 \mathrm{~mL}$ applied every 3 days. Plants irrigated at the highest frequency grew the least total dry weight and had the highest specific root length. Plants with lowest irrigation frequency grew the most and used the least water so had the highest water use efficiency. There were no irrigation frequency effects on relative growth allocation between shoot and roots, net gas exchange of leaves, or on leaf $\mathbf{N}$. A second experiment used identical biweekly irrigation volumes and fertilizer rates, but water and fertilizer were applied using four frequency combinations: 1) daily fertigation; 2) daily irrigation with fertilizer solution applied every 15 days; 3) fertigation every 3 days; or 4) irrigation every 3 days and fertilizer solution applied every 14 days. Total plant growth was unaffected by treatments, but the highest frequency using the lowest fertilizer concentration grew the greatest root dry weight in the uppermost soil depths. Roots grew less and leaf $\mathbf{N}$ was highest when $\mathbf{N}$ was applied every 15 days, implying that root $N$ uptake efficiency was increased when fertigated with the highest fertilizer concentration. All plants had similar water use efficiencies. A third experiment was conducted with irrigation every 3 days and with four different $N$ application frequencies: every $3,6,12$, or 24 days using four fertilizer concentrations but resulting in similar total $\mathrm{N}$ amounts every 24 days. There were no differences in growth, gas exchange, or water use efficiency. Given the fact that all treatments received adequate and equal amounts of water and fertilizer, fertigation frequency had only small effects on plant growth, although very high frequency fertigation decreased $\mathrm{N}$ uptake efficiency.
\end{abstract}

High citrus production and good fruit quality usually depend on irrigation and fertilization, especially in semiarid areas, but also in subtropical humid areas like Florida, where rainfall is seasonal and sandy soils have low water- and nutrient-holding capacities (Koo, 1980). Water-saving irrigation techniques and fertilizer strategies can be used to improve efficiency of water uptake in grapevines (Vitis vinifera L.) and peach trees [Prunus persica (L.) Batsch] (Chalmers et al., 1981; Dry et al., 1996) and also fertilizer use efficiency (Quiñones et al., 2003; Russelle et al., 1981). Because tree growth and yield can be limited by low nitrogen $(\mathrm{N})$ supply (Syvertsen and Sax, 1999), historical emphasis has been on applying sufficient $\mathrm{N}$ to maximize yield (Dasberg, 1987; Tucker et al., 1995).

Nitrogen fertilization exceeding the recommendation rates \{maximum rates of 225

Received for publication 18 Mar. 2010. Accepted for publication 17 June 2010 .

${ }^{1}$ To whom reprint requests should be addressed; e-mail jcmelgar@crec.ifas.ufl.edu.
(2003) estimated an optimal $\mathrm{N}$ rate of $145 \mathrm{~kg}$ $\mathrm{N} / \mathrm{ha}$ for young orange trees [Citrus sinensis (L.) Osbeck] and $260 \mathrm{~kg} \mathrm{~N} / \mathrm{ha}$ for mature trees, although optimal rates depend on factors such as soil type, land history, and yield potential. Low $\mathrm{N}$ fertilizer rates and increased frequency of applications of fertilizer in solution (fertigation) may enhance nutrient use efficiency and tree productivity while minimizing $\mathrm{NO}_{3}$ leaching losses (Alva and Paramasivam, 1998; Syvertsen and Smith, 1996). Good N management has been reported to decrease leaf $\mathrm{Cl}^{-}$concentration in lemon trees [Citrus $\times$ limon (L.) Burm. f.] under salt strees (Gimeno et al., 2009). Fertigation management might also be beneficial to limit excessive root and vegetative flush growth (Yuan et al., 2005) because fertilizer rates can change root density of grapefruit trees (Citrus paradisi Macfad.) (Zhang et al., 1998). Intensively managed irrigation systems may reduce summer growth flush in citrus (Schumann et al., 2009), which could reduce the growth rate of pests like Asian citrus psyllid that feed on new leaves. Psyllids are the vector of Huanglongbing, one of the most devastating diseases in citrus all over the world (Bové, 1986; da Graça, 1991).

Frequent applications of low $\mathrm{N}$ concentrations can minimize residual soil $\mathrm{N}$ that is susceptible to leaching (Willis and Davies, 1990). Intensively managed fertigation systems, in which trees are fertigated as frequently as daily or hourly, have been proposed as a tool to increase water and $\mathrm{N}$ uptake efficiency (Schumann et al., 2009). Our objectives were to precisely measure daily evapotranspiration (ET) and to make frequent applications of water and fertilizer to determine if different fertigation frequencies with identical rates of $\mathrm{N}$ and water application could alter both daily ET and root and shoot growth of potted Swingle citrumelo [Citrus paradisi Macfad. $\times$ Poncirus trifoliata (L.) Raf.] rootstock seedlings under controlled conditions in a greenhouse. We tested the hypothesis that fertigation frequency determines growth per unit water and $\mathrm{N}$ uptake and, thus, water and $\mathrm{N}$ use efficiency.

\section{Materials and Methods}

Plant material and growth conditions. Three separate experiments were conducted in a greenhouse at the University of Florida/ IFAS, Citrus Research and Education Center, Lake Alfred, FL (long. 28.09 ${ }^{\circ} \mathrm{N}$, lat. $81.73^{\circ}$ $\mathrm{W}$; elevation $51 \mathrm{~m}$ ). For all three experiments, uniform 5- to 6-month-old Swingle citrumelo seedlings were purchased from a commercial nursery and transplanted into $30-\mathrm{cm}$ tall, 2.4-L pots filled with previously autoclaved Candler fine sand soil, a hyperthermic, coated Typic Quartzipsamment containing $\approx 98 \%$ sand and less than $1 \%$ organic matter (Li et al., 2006). The bottom $15 \mathrm{~cm}$ of each pot was filled with air-dried sand, whereas the top $15 \mathrm{~cm}$, which included the entire initial root zone of $\approx 10 \mathrm{~cm}$, was filled with thoroughly wet sand near field capacity. Thus, roots were not subjected to dry soil 
conditions at transplanting. All plants were grown in an unshaded translucent greenhouse for 12 weeks with maximum photosynthetically active radiation (PAR; LI-170; LICOR, Inc., Lincoln, NE) measured above the plants of $1300 \mu \mathrm{mol} \cdot \mathrm{m}^{-2} \cdot \mathrm{s}^{-1}$, natural photoperiods of $\approx 11 \mathrm{~h}$, average day/night temperature of $36{ }^{\circ} \mathrm{C}$ day $/ 2{ }^{\circ} \mathrm{C}$ night, and relative humidity varied between $40 \%$ to $100 \%$. All plants were fertigated with varying volumes corresponding to daily ET calculated gravimetrically by weighing plants daily and estimating ET by difference. Irrigation solution was prepared from a complete $8 \mathrm{~N}-0.9 \mathrm{P}-6.6 \mathrm{~K}-0.1 \mathrm{Mg}$ liquid fertilizer (Growers Fertilizer, Lake Alfred, FL) diluted to the appropriate concentration with deionized water. No leaching from the bottom of the pots was observed.

Expt. 1: Irrigation frequency. Thirty 5-month-old seedlings were arranged randomly in three groups of 10 plants each and one of three irrigation frequencies was applied to each group: 1) $15 \mathrm{~mL}$ per day applied in $101.5-\mathrm{mL}$ pulses applied each hour for $10 \mathrm{~h}$ beginning at $0900 \mathrm{HR}$; 2) $15 \mathrm{~mL}$ per day applied in only one 30-s pulse per day at 0900 HR; or 3) $45 \mathrm{~mL}$ applied every $3 \mathrm{~d}$ at $0900 \mathrm{HR}$. Two different $\mathrm{N}$ rates were applied in this experiment. Seedlings from the first two treatments (those with daily applications) were initially fertigated with $15 \mathrm{~mL}$ of 300 mg N/L per plant per day (378 mg N during the whole experiment; Table 1), whereas those irrigated with $45 \mathrm{~mL}$ every $3 \mathrm{~d}$ received $100 \mathrm{mg} \mathrm{N} / \mathrm{L}$ per plant per day $(126 \mathrm{mg} \mathrm{N}$ during the experiment). Rates from 200 to $400 \mathrm{mg} \mathrm{N} / \mathrm{L}$ are commonly used for fertigation of containerized citrus grown in a potting medium (Scholberg et al., 2002) and similar concentrations have been successfully used in similar experiments (Lea-Cox and Syvertsen, 1993; Syvertsen et al., 2010). Because daily ET increased slightly as plants grew, fertigation volumes increased to as high as $22 \mathrm{~mL}$ per day so weekly fertigation rates increased to as high as $46.2 \mathrm{mg} \mathrm{N}$ per week in the first two treatments and up to $15.3 \mathrm{mg} \mathrm{N}$ per week in the third treatment. These ranges of weekly $\mathrm{N}$ applied should have been sufficient for actively growing seedlings while avoiding any nutrient salt accumulation without leaching (Lea-Cox and Syvertsen, 1996).

Precise irrigation treatments were applied using a custom-built irrigation control system consisting of a programmable microcontroller (BasicX24; NetMedia Inc., Tucson, AZ). The irrigation schedules were set and controlled using a MaxStream 9XStream radio (Digi International, Minnetonka, MN) to connect with a file server in the laboratory. A standard $120-\mathrm{V}$ electric solenoid valve was used to open and close the irrigation line. Fertigations were automatically applied using a Flojet injector pump (ITT Corp., White Plains, NY). Volumetric soil water content was measured periodically using time-domain reflectometry (TDR; Fieldscout 135; Spectrum Tech. Inc., Plainfield, IL) probes that were $20 \mathrm{~cm}$ long. Probes were inserted in the top soil layers and through the bottom of the pots to measure water content in the bottom $20 \mathrm{~cm}$.

Table 1. Nitrogen $(\mathrm{N})$ concentration, total $\mathrm{N}$ applied during the 12 weeks, electrical conductivity (EC), and $\mathrm{pH}$ of the fertigation solutions for all the treatments in Expts. 1, 2, and 3.

\begin{tabular}{lcccr}
\hline Treatment & $\mathrm{N}\left(\mathrm{mg} \cdot \mathrm{L}^{-1}\right)$ & Total N $(\mathrm{mg})$ & $\mathrm{EC}\left(\mathrm{dS} \cdot \mathrm{m}^{-1}\right)$ & $\mathrm{pH}$ \\
\hline Expt. 1 & & & & \\
1.5 mL 10 pulses/day & 300 & $378-554.4$ & 2.97 & 6.21 \\
$15 \mathrm{~mL} \mathrm{1} \mathrm{pulse/day}$ & 300 & $378-554.4$ & 2.97 & 6.21 \\
$45 \mathrm{~mL} \mathrm{1} \mathrm{pulse/3} \mathrm{d}$ & 100 & $126-183.6$ & 1.26 & 7.08 \\
& & & & \\
Expt. 2 & 20 & $25.2-54$ & 0.59 & 8.10 \\
Fertigation daily & 300 & $25.2-54$ & 2.97 & 6.21 \\
Water daily; fertigation every 15 d & 20 & $25.2-54$ & 0.59 & 8.10 \\
Fertigation every 3 d & 100 & $25.2-54$ & 1.26 & 7.08 \\
Water every 3 d; fertigation every 15 d & & & & \\
& & & & \\
Expt. 3 & 30 & $42-63.6$ & 0.68 & 7.89 \\
N every 3 d & 60 & $42-63.6$ & 0.92 & 7.47 \\
N every 6 d & 120 & $42-63.6$ & 1.38 & 6.99 \\
N every 12 d & 240 & $42-63.6$ & 1.70 & 6.85 \\
N every 24 d & & & & \\
\end{tabular}

Table 2. Expt. 1: Effects of three different irrigation frequencies on mean $(n=10)$ root, stem and leaf dry weight (DW, g), shoot DW, total plant DW (TPDW, g), root length (m), specific root length (SRL, $\left.\mathrm{m} \cdot \mathrm{g}^{-1}\right)$, leaf dry weight per area (LDW/A, $\left.\mathrm{g} \cdot \mathrm{m}^{-2}\right)$, shoot/root ( $\mathrm{S} / \mathrm{R}$, dimensionless), accumulated evapotranspiration $\left(\mathrm{ET}_{\text {total }}, \mathrm{mL}\right)$, and $\mathrm{WUE}_{\mathrm{WP}}\left(\mathrm{g} \cdot \mathrm{kg}^{-1}\right){ }^{\mathrm{z}}$

\begin{tabular}{llcccccccccc}
\hline Irrigation & Root & Stem & Leaf & Shoot & \multicolumn{7}{c}{ Root } \\
frequency & DW & DW & DW & DW & TPDW & length & SRL & LDW/A & S/R & $E_{\text {total }}$ & WUE $_{\text {WP }}$ \\
\hline 10 pulses/day & $5.8 \mathrm{~b}^{\mathrm{y}}$ & $3.4 \mathrm{c}$ & 1.6 & $5.1 \mathrm{~b}$ & $10.8 \mathrm{~b}$ & 31.8 & $5.5 \mathrm{a}$ & 88.9 & 0.9 & $1538 \mathrm{a}$ & $7.8 \mathrm{~b}$ \\
1 pulse/day & $6.2 \mathrm{ab}$ & $3.7 \mathrm{~b}$ & 1.7 & $5.4 \mathrm{a}$ & $11.6 \mathrm{a}$ & 33.0 & $5.3 \mathrm{a}$ & 88.7 & 0.9 & $1360 \mathrm{~b}$ & $8.5 \mathrm{a}$ \\
1 pulse/3days & $6.7 \mathrm{a}$ & $4.0 \mathrm{a}$ & 1.7 & $5.7 \mathrm{a}$ & $12.3 \mathrm{a}$ & 31.0 & $4.7 \mathrm{~b}$ & 88.1 & 0.9 & $1270 \mathrm{c}$ & $9.0 \mathrm{a}$ \\
$\mathrm{CV}(\%)$ & 8.9 & 6.3 & 7.1 & 5.2 & 5.9 & 12.9 & 10.0 & 4.1 & 8.5 & 2.4 & 6.0 \\
\hline
\end{tabular}

${ }^{\mathrm{z}}$ Measurements were made after $80 \mathrm{~d}$ of treatment.

${ }^{y}$ Within each column, different letters indicate significant differences at $P \leq 0.05$.

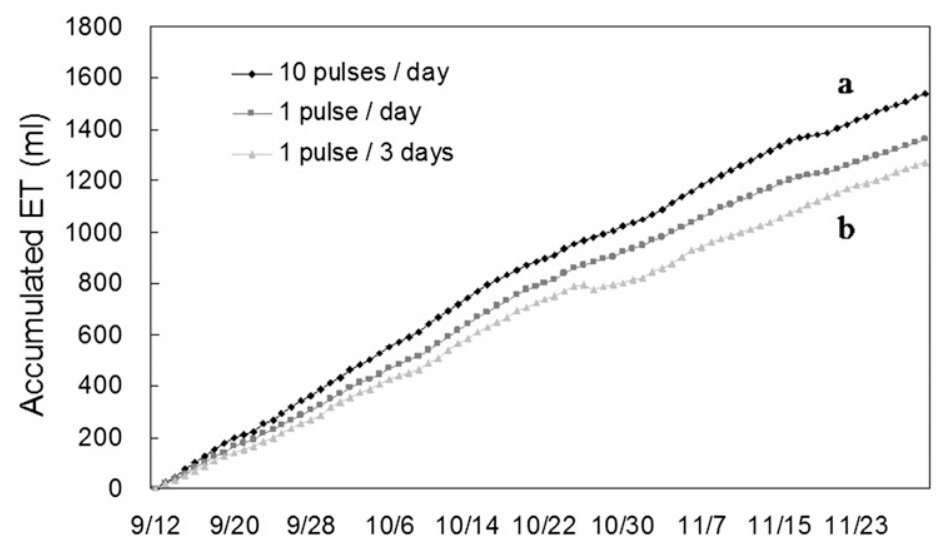

Fig. 1. Expt. 1. Effects of irrigation frequency on mean $(n=10)$ accumulated plant evapotranspiration (ET). Significant differences $(P=0.0112)$ were observed between the linear regression corresponding to the 10 pulses/day treatment $\left(\mathrm{y}=19.62 \mathrm{x}+45.95 ; R^{2}=0.99\right)$ and one pulse $/ 3 \mathrm{~d}$ treatment $(\mathrm{y}=16.21 \mathrm{x}+$ $13.75 ; R^{2}=0.99$ ).

Expt. 2: Irrigation and fertigation frequency. Forty 6-month-old seedlings were transplanted into pots as described for Expt. 1 in four groups of 10 replicate plants and one of four treatments were applied: 1) daily fertigation of $20 \mathrm{mg} \mathrm{N} / \mathrm{L}$; 2) daily irrigation and fertigation every $15 \mathrm{~d}$ with $300 \mathrm{mg} \mathrm{N} / \mathrm{L}$; 3) fertigation every $3 \mathrm{~d}$ with $20 \mathrm{mg} \mathrm{N} / \mathrm{L}$; or 4) irrigation every $3 \mathrm{~d}$ and fertigation every $15 \mathrm{~d}$ with $100 \mathrm{mg} \mathrm{N} / \mathrm{L}$ (Table 1). Volumes of irrigation or fertigation water varied from 15 to $32 \mathrm{~mL}$ per plant per day depending on ET so all seedlings from all treatments received identical total amounts of water and $\mathrm{N}$ that varied from 25.2 to $54.0 \mathrm{mg} \mathrm{N}$. These rates of $\mathrm{N}$ were considerably lower than those applied
Table 3. Expt. 1: Effects of three different irrigation frequencies on mean $(\mathrm{n}=10)$ leaf nitrogen $\left(\mathrm{N}_{\mathrm{g}}\right.$ basis: \%, g N/g leaf DW; and $\mathrm{N}_{\mathrm{a}}$ basis: $\mathrm{g} \cdot \mathrm{m}^{-2}$ ) and $\mathrm{N}$ use efficiency (NUE; $\left.\mathrm{g} \cdot \mathrm{g}^{-1}\right)^{\mathrm{z}}$

\begin{tabular}{llcc}
\hline Irrigation & & & \\
frequency & $\mathrm{N}_{\mathrm{g}}(\%)$ & $\mathrm{N}_{\mathrm{a}}\left(\mathrm{g} \cdot \mathrm{m}^{-2}\right)$ & $\mathrm{NUE}$ \\
\hline 10 pulses/day & $2.8 \mathrm{~b}^{\mathrm{y}}$ & 5.0 & $26.1 \mathrm{~b}$ \\
1 pulse/day & $2.9 \mathrm{ab}$ & 5.2 & $28.2 \mathrm{~b}$ \\
1 pulse/3 days & $3.0 \mathrm{a}$ & 5.3 & $90.0 \mathrm{a}$ \\
$\mathrm{CV}(\%)$ & 3.9 & 6.1 & 7.9 \\
\hline
\end{tabular}

${ }^{2}$ Measurements were made after $80 \mathrm{~d}$ of treatment. ${ }^{\mathrm{y}}$ Within each column, different letters indicate significant differences at $P \leq 0.05$. 
in the previous experiment because in this second experiment, there were two treatments with $\mathrm{N}$ applications every $15 \mathrm{~d}$ and we were concerned about potential salt accumulation when using high fertilizer concentrations without leaching. Thus, to supply the total amount of $\mathrm{N}$ without exceeding $300 \mathrm{mg} \cdot \mathrm{L}^{-1}$, we reduced the rate of $\mathrm{N}$. Fertigation treatments were applied using a manual pipette.

Expt. 3: Uniform irrigation but varied fertigation frequency. Thirty-six 6-monthold seedlings were established as described previously in four groups of nine replicate plants. All plants received similar amounts of water every $3 \mathrm{~d}$ but with one of four fertigation treatments: 1) fertigation every $3 \mathrm{~d}$ with $30 \mathrm{mg} \mathrm{N} / \mathrm{L}$; 2) irrigation alternating with fertigation every $3 \mathrm{~d}$ with $60 \mathrm{mg} \mathrm{N} / \mathrm{L} ; 3$ ) irrigation every $3 \mathrm{~d}$ and fertigation every $12 \mathrm{~d}$ with $120 \mathrm{mg} \mathrm{N} / \mathrm{L}$; or 4) irrigation every $3 \mathrm{~d}$ and fertigation every $24 \mathrm{~d}$ with $240 \mathrm{mg} \mathrm{N} / \mathrm{L}$ (Table 1). Volumes of irrigation water varied from 16.7 to $25 \mathrm{~mL}$ per plant per day depending on ET, but all seedlings received identical total amounts on $\mathrm{N}$ that varied from $\approx 42.0$ to $63.6 \mathrm{mg} \mathrm{N}$ during the experiment. Fertigation treatments were applied like in Expt. 2 using a manual pipette.

Stem water potential. Midday (near 1200 HR) stem water potential (SWP; McCutchan and Shackel, 1992) was measured in six mature leaves per treatment in the first experiment. Leaves to be measured were placed in aluminum foil-covered plastic bags for at least $1 \mathrm{~h}$ before measurement. Stem water potential was measured at the middle ( 6 weeks) and at the end (11 weeks) of treatments in Expt. 1 using a Scholander-type pressure chamber (PMS Instrument, Corvallis, OR; Scholander et al., 1965).

Gas exchange and leaf water relations. In Expts. 2 and 3, net gas exchange of leaves was measured 11 weeks after the initiation of the treatments using fully expanded single leaves from the middle of the shoot of five replicate plants per treatment. Net assimilation of $\mathrm{CO}_{2}\left(\mathrm{~A}_{\mathrm{CO} 2}\right)$, stomatal conductance, leaf transpiration $\left(\mathrm{E}_{\mathrm{lf}}\right)$, and instantaneous water use efficiency $\left(\mathrm{WUE}_{\mathrm{lf}}=\mathrm{A}_{\mathrm{CO} 2} / \mathrm{E}_{\mathrm{lf}}\right)$ were determined with a portable photosynthesis system (LI-6200; LICOR, Inc.) using a $250-\mathrm{cm}^{3}$ cuvette. Measurements were made in the morning ( $0900 \mathrm{HR}$ TO $1100 \mathrm{HR}$ ) to avoid high afternoon temperatures and low humidity, which can cause midday depression of net gas exchange (Hu et al., 2009; Jifon and Syvertsen, 2003). During all gas exchange measurements, conditions within the cuvette were: $P A R$ greater than $800 \mu \mathrm{mol} \cdot \mathrm{m}^{-2} \cdot \mathrm{s}^{-1}$, leaf temperature $27 \pm 5{ }^{\circ} \mathrm{C}$, and leaf to air water vapor pressure difference $1.8 \pm 0.5 \mathrm{kPa}$.

Growth and nutrient concentration. In all three experiments, plants were harvested after 12 weeks of treatment. Leaves, stems, and roots were separated and fresh weights measured. Total leaf area was measured with a leaf area meter (LI-3000; LICOR, Inc.) in combination with a transparent belt conveyor accessory (LI-3050A; LICOR, Inc.). Roots from the second and third experiments were divided in three groups by depths of: 0 to 10 $\mathrm{cm}, 10$ to $20 \mathrm{~cm}$, and 20 to $30 \mathrm{~cm}$. Root length at each depth was estimated using a lineintercept method (Tennant, 1975) and the amount of root length per unit root biomass or specific root length (SRL, m/g) was calculated. All leaves were briefly rinsed with deionized water, oven-dried at $60{ }^{\circ} \mathrm{C}$ for at least $48 \mathrm{~h}$, weighed, and ground to a powder. Total dry weights of leaves, stems, and roots were summed as total plant dry weight (TPDW); leaf dry weight/leaf area (LDW/ A) and shoot/root dry weight ratio (S/R) were calculated. Because all seedlings were similar in size at the beginning of each experiment, an estimate of whole plant water use efficiency (WUE $\mathrm{WP}_{\mathrm{P}}$ ) was calculated as TPDW/total water consumed during the 12 weeks and expressed in units of $\mathrm{g} \cdot \mathrm{kg}^{-1}$. Leaf $\mathrm{N}$ concentrations were determined by a commercial analytical laboratory (Waters Agricultural Laboratory, Camilla, GA) and expressed as mg/g dry weight (DW) and also as $\mathrm{mmol} \cdot \mathrm{m}^{-2}$. Whole plant $\mathrm{N}$ use efficiency (NUE) was estimated as TPDW/total N applied $\left(\mathrm{g} \cdot \mathrm{g}^{-1}\right)$ during the 12 weeks (Sorgona et al., 2006).

Experimental design and data analysis. Data from each experiment were analyzed separately using analysis of variance (SAS Institute Inc., Cary, NC) as completely randomized designs with nine or 10 replicate plants per treatment. When a significant F-test was observed, Duncan's multiple range test $(P \leq 0.05)$ was used to separate means. The slopes of the fitted linear regression lines to accumulated ET data within each experiment were compared using a $t$ test (Sigmaplot 10.0; Systat Software Inc., Chicago, IL).

\section{Results}

Expt. 1. Midday SWP varied between -0.6 and $-0.9 \mathrm{MPa}$ and there were no SWP differences attributable to treatment after 6 or

Table 4. Expt. 2: Effects of four combinations of irrigation frequencies and nitrogen (N) application on mean $(\mathrm{n}=10)$ root, stem and leaf DW $(\mathrm{g})$, shoot DW, total plant DW (TPDW, g), root length (m), specific root length $\left(\mathrm{SRL}, \mathrm{m} \cdot \mathrm{g}^{-1}\right)$, leaf dry weight per area $\left(\mathrm{LDW} / \mathrm{A}, \mathrm{g} \cdot \mathrm{m}^{-2}\right)$, shoot/root $(\mathrm{S} / \mathrm{R}$, dimensionless), accumulated evapotranspiration $\left(\mathrm{ET}_{\text {total }}, \mathrm{mL}\right)$, and $\mathrm{WUE}_{\mathrm{WP}}\left(\mathrm{g} \cdot \mathrm{kg}^{-1}\right){ }^{\mathrm{z}}$

\begin{tabular}{lccccccccccc}
\hline $\begin{array}{l}\text { Irrigation and N } \\
\text { application }\end{array}$ & $\begin{array}{l}\text { Root } \\
\text { DW }\end{array}$ & $\begin{array}{c}\text { Stem } \\
\text { DW }\end{array}$ & $\begin{array}{c}\text { Leaf } \\
\text { DW }\end{array}$ & $\begin{array}{c}\text { Shoot } \\
\text { DW }\end{array}$ & $\begin{array}{c}\text { TPDW } \\
\text { length }\end{array}$ & SRL & LDW/A & S/R & ET $_{\text {total }}$ & WUE \\
\hline $\begin{array}{l}\text { Water daily } \\
\text { N daily }\end{array}$ & $3.7 \mathrm{a}^{\mathrm{y}}$ & 2.4 & 1.5 & 3.8 & 7.6 & $22.3 \mathrm{a}$ & 6.1 & 71.3 & 1.1 & $2066 \mathrm{a}$ & 4.0 \\
$\begin{array}{l}\text { Water daily } \\
\text { N every 2 weeks }\end{array}$ & $2.7 \mathrm{~b}$ & 2.0 & 1.4 & 3.5 & 6.2 & $18.0 \mathrm{ab}$ & 6.6 & 72.7 & 1.3 & $1983 \mathrm{ab}$ & 3.2 \\
$\begin{array}{l}\text { Water every 3 d } \\
\text { N every 3 d }\end{array}$ & $3.1 \mathrm{ab}$ & 2.1 & 1.4 & 3.5 & 6.6 & $20.5 \mathrm{a}$ & 6.7 & 73.3 & 1.2 & $1901 \mathrm{bc}$ & 3.5 \\
$\begin{array}{l}\text { Water every 3 d } \\
\text { N every 2 weeks }\end{array}$ & $2.6 \mathrm{~b}$ & 1.9 & 1.4 & 3.2 & 5.8 & $14.6 \mathrm{~b}$ & 6.0 & 77.2 & 1.3 & $1840 \mathrm{c}$ & 3.1 \\
CV (\%) & 24.7 & 23.6 & 20.8 & 22.0 & 20.9 & 22.5 & 19.6 & 15.3 & 24.3 & 3.9 & 20.9 \\
\hline
\end{tabular}

${ }^{\mathrm{z}}$ Measurements were made after $80 \mathrm{~d}$ of treatment.

${ }^{\mathrm{y}}$ Within each column, different letters indicate significant differences at $P \leq 0.05$.

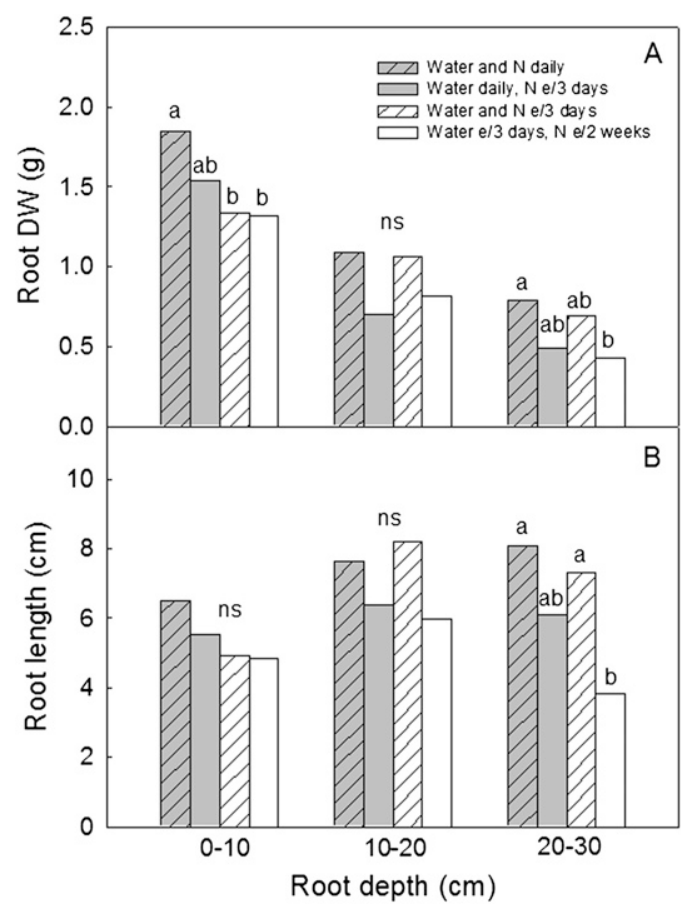

Fig. 2. Expt. 2. Effects of fertigation frequency on mean $(n=10)$ root dry weight $(\mathbf{A})$ and root length $(\mathbf{B})$ at three soil depth intervals: 0 to 10,10 to 20,20 to $30 \mathrm{~cm}$. Within each depth interval, different letters indicate significant differences at $P \leq 0.05$; NS $=$ nonsignificantly different. 
11 weeks of treatments (data not shown). The highest irrigation frequency ( 10 hourly pulses per day) significantly decreased root and shoot growth because these seedlings grew the least TPDW (Table 2). Plants with lowest irrigation frequency not only grew more, but also had the lowest accumulated ET (Fig. 1) and consequently, a $\mathrm{WUE}_{\mathrm{WP}}$ greater than in the treatment with 10 pulses per day (Table 2 ). There were no treatment effects on total leaf DW, leaf area (data not shown), or LDW/ A. Plants with the lowest irrigation frequency had the lowest SRL, or the thickest roots, but there were no irrigation frequency effects on relative growth allocation to shoot and roots because $\mathrm{S} / \mathrm{R}$ was unaffected by treatment. Periodic measurements of soil water content using TDR confirmed that water content at the bottom of the pots was higher in plants receiving less frequent applications of higher volume of water than in the other plants (data not shown).

Although all leaf $\mathrm{N}$ concentrations were above levels considered to be sufficient (greater than $26 \mathrm{mg} \mathrm{N} / \mathrm{g} \mathrm{DW}$ ), leaf $\mathrm{N}$ concentration increased with decreasing fertigation frequency (Table 3), but this difference disappeared when leaf $\mathrm{N}$ was expressed on a leaf area basis. The lowest fertigation frequency that received the lowest $\mathrm{N}$ rate resulted in the highest NUE. Leaf gas exchange parameters, including $\mathrm{WUE}_{\mathrm{lf}}$, were unaffected by treatment (data not shown).

Expt. 2. Leaf, stem and total plant growth (TPDW) were unaffected by treatments (Table 4). Although the total accumulated ET was highest with the daily fertigation and lowest with the least frequent fertigation of

Table 5. Expt. 2: Effects of four combinations of irrigation frequencies and nitrogen (N) application on mean $(\mathrm{n}=10)$ leaf $\mathrm{N}\left(\mathrm{N}_{\mathrm{g}}\right.$ basis: \%, $\mathrm{g} \mathrm{N} / \mathrm{g}$ leaf $\mathrm{DW}$; and $\mathrm{N}_{\mathrm{a}}$ basis: $\mathrm{g} \cdot \mathrm{m}^{-2}$ ) and $\mathrm{N}$ use efficiency (NUE; $\mathrm{g} \cdot \mathrm{g}^{-1}$ ). ${ }^{\mathrm{z}}$

\begin{tabular}{|c|c|c|c|}
\hline $\begin{array}{l}\text { Irrigation and } \mathrm{N} \\
\text { application }\end{array}$ & $\mathrm{N}_{\mathrm{g}}$ & $\mathrm{N}_{\mathrm{a}}$ & NUE \\
\hline Water daily & $2.4 \mathrm{~b}^{\mathrm{y}}$ & $3.5 \mathrm{~b}$ & 199.6 \\
\hline $\mathrm{N}$ daily & & & \\
\hline $\begin{array}{l}\text { Water daily } \\
\mathrm{N} \text { every } 2 \text { weeks }\end{array}$ & $2.9 \mathrm{a}$ & $4.3 \mathrm{ab}$ & 160.7 \\
\hline $\begin{array}{l}\text { Water every } 3 \mathrm{~d} \\
\mathrm{~N} \text { every } 3 \mathrm{~d}\end{array}$ & $2.9 \mathrm{a}$ & $4.3 \mathrm{ab}$ & 176.1 \\
\hline $\begin{array}{l}\text { Water every } 3 \mathrm{~d} \\
\mathrm{~N} \text { every } 2 \text { weeks }\end{array}$ & $2.9 \mathrm{a}$ & $4.5 \mathrm{a}$ & 158.3 \\
\hline $\mathrm{CV}(\%)$ & 6.4 & 18.6 & 20.9 \\
\hline
\end{tabular}

every 2 weeks, there were no treatment effects on $W_{W} E_{W P}$. Total root DW was greatest with daily fertigation, whereas total root length was greatest for the frequent fertigations. Averaging overall soil depths, however, there were no changes in SRL as a result of the fertigation treatments. Root DW tended to be greatest at soil depths above $10 \mathrm{~cm}$ and below $20 \mathrm{~cm}$ when seedlings were fertigated daily, although there was overall less root DW at the deepest soil depth interval (Fig. 2A). Root length also was greatest below $20 \mathrm{~cm}$ in the daily fertigation treatment (Fig. 2B). When $\mathrm{N}$ was applied only every 2 weeks, there was less root DW and less root length below $20 \mathrm{~cm}$.

Seedlings with the highest fertigation frequency, the daily fertigation treatment with the lowest concentration of $\mathrm{N}$, took up the least $\mathrm{N}$ because they had lower values of leaf $\mathrm{N}$, regardless of unit of expression, than other treatments (Table 5). However, there was no treatment effect on NUE.

Expt. 3. When all treatments were irrigated every $3 \mathrm{~d}$, there were no fertigation frequency effects on total ET or WUE $E_{W P}$ (Table 6). In addition, the different fertigation frequencies did not affect any of the measured growth parameters even when roots were separated in three $10-\mathrm{cm}$ depth intervals (data not shown). Different $\mathrm{N}$ frequencies did not have any effect on leaf $\mathrm{N}$ concentration, NUE (Table 6), or any gas exchange parameter, including $\mathrm{WUE}_{\mathrm{lf}}$ (data not shown).

\section{Discussion}

The first experiment showed that low irrigation frequencies in citrus seedlings increased WUE $\mathrm{WP}_{\mathrm{W}}$ and root DW and decreased SRL. Thicker roots tend to decrease water and mineral nutrient transport and can result in lower rates of photosynthesis (Syvertsen and Graham, 1985; Syvertsen et al., 2000). Shoot/root allocation was not altered, however, and total root length was unchanged. As a consequence, the lower SRL was the result of an increased root DW. The lowest SRL observed at the lowest irrigation frequency could have decreased water uptake and, thus, increased $\mathrm{WUE}_{\mathrm{WP}}$. Also, the lowest WUE $\mathrm{WP}_{\mathrm{WP}}$ in plants with high irrigation frequency could have been the result of a presumably higher evaporation rate from the soil surface after every pulse than after the less frequent applications of higher volumes. Water from the treatment of hourly $1.5-\mathrm{mL}$ pulses prob- ably would have remained mostly in the shallow soil layers, especially during the first pulses every day, after irrigation water redistributed overnight.

The plants with the lowest fertigation frequency (where the lowest $\mathrm{N}$ rates were applied) had the highest NUE, as also reported in apple trees (Malus domestica Borkh.) by Neilsen and Neilsen (2002). The high leaf N concentration, greater plant growth, and higher $W E_{W P}$ observed at the lowest irrigation frequency in the first experiment were the basis for developing the second experiment with daily or every 3-d irrigation frequencies as well as different frequencies of fertilizer application. In earlier field studies, there was a decrease in root density when $\mathrm{N}$ was applied at excess levels (Ford et al., 1957), but there was an increase in root density if $\mathrm{N}$ was applied within optimum levels (Zhang et al., 1998). In the second experiment, we did not observe changes in shoot growth, total plant growth, or water and $\mathrm{N}$ use efficiency, but root growth was increased in plants with the highest fertigation frequencies. Root development response to fertilizer nutrients is more sensitive than leaves (Zhang et al., 1998) and we observed that differences in root growth among treatments were mostly the result of roots at the $20-$ to $30-\mathrm{cm}$ depth. Increases in citrus root growth and decreases in $S / R$ ratio under low irrigation frequency has been reported to be an adaptive mechanism to exploit more soil volume (Syvertsen and Hanlon, 2008). However, the differences in root growth found in our seedlings were a consequence of the $\mathrm{N}$ fertilization more than the irrigation frequency because roots can adapt to non-uniform distributions of soil resources (Sultan, 2000). Plants fertigated daily had higher root DW and consequently a larger percentage of roots near the surface than plants irrigated every 3 d (Cahoon et al., 1961; Castle, 1974). This has also been observed in other fruit tree species like apple (Malus domestica Borkh.) (Beukes, 1984) and peach [Prunus persica (L.) Batsch] (Layne et al., 1986).

In the third experiment, when irrigation was applied every $3 \mathrm{~d}$ with a similar amount of total $\mathrm{N}$ applied in all the treatments, $\mathrm{N}$ application frequency had no effect on growth, water use, or leaf N. Thus, fertigation frequency was of no consequence (Ferguson et al., 1990; Koo, 1980; Weinert et al., 2002) when application rates were similar. In all the three experiments, leaf $\mathrm{N}$ concentration was always within the optimal range supporting

Table 6. Expt. 3: Effects of four fertilization frequencies on mean $(n=9)$ root, stem and leaf dry weight (DW; g), shoot DW, total plant DW (TPDW, g), root length $(\mathrm{m})$, specific root length (SRL, $\left.\mathrm{m} \cdot \mathrm{g}^{-1}\right)$, leaf dry weight per area (LDW/A, $\left.\mathrm{g} \cdot \mathrm{m}^{-2}\right)$, shoot/root $\left(\mathrm{S} / \mathrm{R}\right.$, dimensionless), accumulated evapotranspiration $\left(\mathrm{ET}_{\text {total }}\right.$, $\mathrm{mL}), \mathrm{WUE}_{\mathrm{WP}}\left(\mathrm{g} \cdot \mathrm{kg}^{-1}\right)$, leaf $\mathrm{N}\left(\mathrm{mg} \cdot \mathrm{g}^{-1} \mathrm{DW}\right)$, and $\mathrm{N}$ use efficiency $\left(\mathrm{NUE} ; \mathrm{g} \cdot \mathrm{g}^{-1}\right) .^{\mathrm{z}}$

\begin{tabular}{|c|c|c|c|c|c|c|c|c|c|c|c|c|c|}
\hline $\begin{array}{l}\text { Fertigation } \\
\text { frequency }\end{array}$ & $\begin{array}{l}\text { Root } \\
\text { DW }\end{array}$ & $\begin{array}{l}\text { Stem } \\
\text { DW }\end{array}$ & $\begin{array}{l}\text { Leaf } \\
\text { DW }\end{array}$ & $\begin{array}{l}\text { Shoot } \\
\text { DW }\end{array}$ & TPDW & $\begin{array}{l}\text { Root } \\
\text { length }\end{array}$ & SRL & LDW/A & $\mathrm{S} / \mathrm{R}$ & $\mathrm{ET}_{\text {total }}$ & WUE $_{W P}$ & Leaf $N$ & NUE \\
\hline $\mathrm{N}$ every $6 \mathrm{~d}$ & 4.0 & 2.9 & 1.6 & 4.5 & 8.5 & 29.8 & 7.5 & 87.7 & 1.2 & 1573 & 5.1 & 30.2 & 151.3 \\
\hline $\mathrm{N}$ every $12 \mathrm{~d}$ & 3.6 & 2.9 & 1.5 & 4.3 & 7.9 & 25.6 & 7.1 & 89.8 & 1.3 & 1575 & 4.7 & 30.7 & 135.2 \\
\hline $\mathrm{CV}(\%)$ & 32.0 & 23.7 & 26.8 & 22.9 & 25.6 & 35.5 & 17.8 & 8.5 & 19.5 & 7.0 & 25.0 & 8.9 & 25.9 \\
\hline
\end{tabular}

${ }^{\mathrm{z}}$ Measurements were made after $80 \mathrm{~d}$ of treatment. No letters within each column indicates no significant differences. 
the concept that increased $\mathrm{N}$ rates in wellnourished trees are not reflected in changes in leaf N concentrations (Du Sautoy, 1992; Smith, 1954).

In conclusion, water was a better growth regulator than fertilizer because less frequent fertigations increased water use efficiency, decreasing root growth but without altering shoot growth. In addition, infrequent fertigation did not affect $\mathrm{N}$ use efficiency, growth, or $\mathrm{WUE}_{\mathrm{WP}}$. These results are thought to be beneficial for citrus nurseries but will have to be carefully considered in field-grown citrus trees whose susceptibility to significant nutrient leaching losses from rainfall would increase with decreasing fertigation frequency, thus reducing NUE.

\section{Literature Cited}

Alva, A.K. and S. Paramasivam. 1998. Nitrogen management for high yield and quality of citrus in sandy soils. Soil Sci. Soc. Amer. J. 62:13351342.

Bacchus, S.T. and P.J. Barile. 2005. Discriminating sources and flowpaths of anthropogenic nitrogen discharges to Florida springs, streams and lakes. Environ. Eng. Geosci. 11:347-369.

Beukes, D.J. 1984. Apple root distribution as affected by irrigation at different soil water levels on two soil types. J. Amer. Soc. Hort. Sci. 109:723-728.

Bové, J.M. 1986. Huanglongbing: A destructive, newly-emerging century-old disease of citrus. J. Plant Pathol. 88:7-37.

Cahoon, G.A., M.R. Huberty, and M.J. Garber. 1961. Irrigation frequency effects on citrus root distribution and density. Proc. Am. Soc. Hort. Sci. 77:167-172.

Castle, W.S. 1974. The effect of depth of rooting on citrus root structure and water absorption. $\mathrm{PhD}$ Diss., Univ. of Florida, Gainesville, FL.

Chalmers, D.J., P.D. Mitchell, and L. van Heek. 1981. Control of peach tree growth and productivity by regulated water supply, tree density and summer pruning. J. Amer. Soc. Hort. Sci. 111:904-907.

da Graça, J.V. 1991. Citrus greening disease. Annu. Rev. Phytopathol. 26:109-136.

Dasberg, S. 1987. Nitrogen fertilization in citrus orchards. Plant Soil 100:1-9.

Dry, P.R., B.R. Loveys, D. Botting, and H. During. 1996. Effects of partial rootzone drying on grapevine vigour, yield, composition of fruit and use of water. Proc. Aust. Wine Ind. Tech. Conf. 9:126-131.

Du Sautoy, N. 1992. Field trial evaluation of 'Valencia' fruiting terminal leaf $\mathrm{P}, \mathrm{K}$, and $\mathrm{Mg}$ norms for a low base status loamy sand. Proc. Intl. Soc. Citricult. 2:547-550.

Ferguson, J.J., F.S. Davies, and J.M. Bulger. 1990. Fertigation and growth of young 'Sunburst' tangerine trees. Proc. Fla. State Hort. Soc. 103:8-9.

Ford, H.W., W. Reuther, and P.F. Smith. 1957. Effect of nitrogen on root development of Valencia orange trees. Proc. Am. Soc. Hort. Sci. 70:237-244.

Gimeno, V., J.P. Syvertsen, M. Nieves, I. Simón, V. Martínez, and F. García-Sánchez. 2009. Additional nitrogen fertilization affects salt tolerance of lemon trees on different rootstocks. Sci. Hort. 121:298-305.

Hu, M.J., Y.P. Guo, Y.G. Shen, D.P. Guo, and D.Y. Li. 2009. Midday depression of photosynthesis and effects of mist spray in citrus. Ann. Appl. Biol. 154:143-155.

Jifon, J.L. and J.P. Syvertsen. 2003. Moderate shade can increase net gas exchange and reduce photoinhibition in citrus leaves. Tree Physiol. 23:119-127.

Koo, C.J. 1980. Results of citrus fertigation studies. Proc. Fla. State Hort. Soc. 93:33-36.

Lamb, S.T., W.D. Graham, C.B. Harrison, and A. Alva. 1999. Impact of alternative citrus management practices on groundwater nitrate in the Central Florida Ridge. Part I. Field investigation. Trans. ASAE 42:1653-1668.

Layne, R.E.C., C.S. Tan, and R.L. Perry. 1986. Characterization of peach roots in Fox sand as influenced by sprinkler irrigation and tree density. J. Amer. Soc. Hort. Sci. 111:670-677.

Lea-Cox, J.D. and J.P. Syvertsen. 1993. Salinity reduces water use and nitrate-N-use efficiency of Citrus. Ann. Bot. (Lond.) 72:47-54.

Lea-Cox, J.D. and J.P. Syvertsen. 1996. How nitrogen supply affects growth, nitrogen uptake, use efficiency and loss from Citrus seedlings. J. Amer. Soc. Hort. Sci. 121:105-114.

Legaz, F. and E. Primo-Millo. 1988. Guidelines for Citrus fertilization. Technical Report, Department of the Agriculture, Fish and Food of the Valencian Government, Valencia, Spain. No. 5-88 [in Spanish].

Li, H., J.P. Syvertsen, C.W. McCoy, R.J. Stuart, and A.W. Schumann. 2006. Water stress and root injury from simulated flooding and Diaprepes abbreviatus root weevil larval feeding in citrus. Soil Sci. 171:1-14.

McCutchan, H. and K.A. Shackel. 1992. Stemwater potential as a sensitive indicator of water stress in Prune trees (Prunus domestica L. cv. French). J. Amer. Soc. Hort. Sci. 117:607-611.

Neilsen, D. and G.H. Neilsen. 2002. Efficient use of nitrogen and water in high density apple orchards. HortTechnology 12:19-25.

Obreza, T.A., K.T. Morgan, L.G. Albrigo, and B.J. Boman. 2008. Recommended fertilizer rates and timing, p. 48-59. In: Obreza, T.A. and K.T. Morgan (eds.). Nutrition of Florida citrus trees. Univ. of Florida-IFAS, Gainesville, FL.

Paramasivam, S., A.K. Alva, and A. Fares. 2000. An evaluation of soil water status using tensiometers in a sandy soil profile under citrus production. Soil Sci. 165:343-353.

Quiñones, A., J. Bañuls, E. Primo-Millo, and F. Legaz. 2003. Effects of ${ }^{15} \mathrm{~N}$ application frequency on nitrogen uptake efficiency in Citrus trees. J. Plant Physiol. 160:1429-1434.

Riotte, W. 1994. Ridge citrus water quality project annual (1993) report. Fla. Dept. Agr. Consum. Serv., Tallahassee, FL.

Russelle, M.P., E.J. Deibert, R.D. Hauck, M. Stevanovic, and R.A. Olson. 1981. Effects of water and nitrogen management on yield and ${ }^{15} \mathrm{~N}$-depleted fertilizer use efficiency of irrigated corn. Soil Sci. Soc. Amer. J. 45:553558.

Scholander, P., H. Hammel, E. Bradstreet, and E. Hemmingsen. 1965. Sap pressure in vascular plants. Science 148:339-345.

Scholberg, J.M.S., L.R. Parsons, T.A. Wheaton, B.L. McNeal, and K.T. Morgan. 2002. Soil temperature, nitrogen concentration and residence time affect nitrogen uptake efficiency in Citrus. J. Environ. Qual. 31:759-768.

Schumann, A.W., A. Fares, A.K. Alva, and S. Paramasivam. 2003. Response of 'Hamlin' orange to fertilizer source annual rate and irrigated area. Proc. Fla. State Hort. Soc. 116: 256-260.
Schumann, A.W., J.P. Syvertsen, and K.T. Morgan. 2009. Implementing advanced citrus production systems in Florida-Early results. Proc. Fla. State Hort. Soc. 122:108-113.

Smith, P.F. 1954. Citrus nutrition, p. 174-207. In: Childers, N.F. (ed.). Fruit nutrition. Temperate to tropical. Horticultural Publications, RutgersThe State University, New Brunswick, NJ.

Sorgona, A., M.R. Abenavoli, P.G. Gringeri, and G. Cacco. 2006. A comparison of nitrogen use efficiency definitions in Citrus rootstocks. Sci. Hort. 109:389-393.

Sultan, S.E. 2000. Phenotypic plasticity for plant development, function and life history. Trends Plant Sci. 5:537-542.

Syvertsen, J.P. and J.H. Graham. 1985. Hydraulic conductivity of roots, mineral nutrition, and leaf gas exchange of citrus rootstocks. J. Amer. Soc. Hort. Sci. 119:865-869.

Syvertsen, J.P. and E.A. Hanlon. 2008. Citrus trees stresses: Effects on growth and yield. Univ. of Florida-IFAS, Gainesville, FL. Publ. \# HS1138.

Syvertsen, J.P., L.S. Lee, and J.W. Grosser. 2000. Limitations on growth and net gas exchange of diploid and tetraploid citrus rootstock seedlings grown at elevated $\mathrm{CO}_{2}$. J. Amer. Soc. Hort. Sci. 125:228-234.

Syvertsen, J.P., J.C. Melgar, and F. García-Sánchez. 2010. Salinity tolerance and leaf water use efficiency in Citrus. J. Amer. Soc. Hort. Sci. 135:33-39.

Syvertsen, J.P. and S.M. Sax. 1999. Fertigation frequency, wetting patterns and nitrate leaching from lysimeter-grown citrus trees Proc. Fla. State Hort. Soc. 112:9-14.

Syvertsen, J.P. and M.L. Smith. 1996. Nitrogen uptake efficiency and leaching losses from lysimeter-grown Citrus trees fertilized at three nitrogen rates. J. Amer. Soc. Hort. Sci. 121:5762.

Tennant, D. 1975. A test of a modified line intersect method of estimating root length. J. Ecol. 63: 995-1001.

Tucker, D.P.H., A.K. Alva, L.K. Jackson, and T.A. Wheaton. 1995. Nutrition of Florida citrus trees. Univ. of Florida-IFAS, Gainesville, FL. Publ. \# SP 169.

U.S. Department of Health, Education, and Welfare. 1962. Public health service drinking water standards. Publication 956. U.S. Department of Health, Education, and Welfare, Washington, DC.

Weinert, T.L., T.L. Thompson, and S.A. White 2002. Nitrogen fertigation of young navel oranges: Growth, N status, and uptake of fertilizer. HortScience 37:334-337.

WHO. 2004. Guidelines for drinking water quality. Recommendations, 3rd Ed., Vol. 1. World Health Organization, Geneva, Switzerland. 15 July 2010. <http://www.who.int/water_ sanitation_health/dwq/GDWQ2004web.pdf>.

Willis, L.E. and F.S. Davies. 1990. Fertilization, nitrogen leaching and growth of young 'Hamlin' orange trees on two rootstocks. Proc. Fla. State Hort. Soc. 103:30-37.

Yuan, R., F. Alferez, I. Kostenyuk, S. Singh, J.P. Syvertsen, and J.K. Burns. 2005. Partial defoliation can decrease average leaf size but has little effect on orange tree growth, fruit yield and juice quality. HortScience 40:20112015 .

Zhang, M., A.K. Alva, and Y.C. Li. 1998. Fertilizer rates change root distribution of grapefruit trees on poorly drained soil. J. Plant Nutr. 21: $1-11$. 